\title{
Negative or Potential Impacts of Global Climate Change on Ecosystems and Biodiversity
}

\author{
Mark Joseph J. Buncag \\ Palawan State University, Palawan, Philippines \\ mjbuncag@psu.palawan.edu.ph
}

\begin{abstract}
Climate change is a change in the state of climate over time, whether caused by natural variability or anthropogenic activities that affect the biophysical environment and our economy, culture, health, security, and others. The greenhouse gas emission in the Philippines increases due to energy consumption, agricultural activities, industrial processes, wastes, and land-use change. Palawan is the largest province in the Philippines with rich biodiversity and is considered the "Last Ecological Frontier."The province experiencesimpacts of climate change such as extreme weather, storms, floods, destruction of habitats like mangroves, pests and diseases, disturbances of flora and fauna species, changes in water availability, and changes in aquatic and terrestrial productivity, and others. There are numerous Indigenous Cultural communities in the province likePalaw'an, Batak, Tagbanua, Molbog, Tau'tBato. These tribes commonly practice "Kaingin" as their primary farming practices but with different belief systems and traditional knowledge and practices. Tribes experience a decline in rice crop harvest from Kaingin farming for subsistence, decline of water availability accessible to the area, a drop of gathered forest products of about $80 \%-90 \%$ based on estimation, damaged property, and reduction of shells and fish harvest. In response, the communities provide adaptation measures such as planting mangroves, using calendar methods for planting, and coastal protection.
\end{abstract}

Keywords: Climate Change, Indigenous Cultural Communities, Farming Practices

\section{Introduction}

Climate change is one of the contemporary severe environmental problems that we are facing. It affects the biophysical environment and our economy, culture, health, security, and others. It is a change in the state of climate over time, whether caused by natural variability or anthropogenic activities. This phenomenon is caused by the continuous emission of greenhouse gasses in the atmosphere from different anthropogenic activities such as agricultural production, mining operations, power plants, factories, and other industrial activities. Based on the 2019 Global Gas Emission Data of the Environmental Protection Agency (EPA), the $\mathrm{CO}_{2}$ emission has increased by about $90 \%$ since 1970 from fossil fuel combustion and industrial processes, which contributes $78 \%$ of the total greenhouse emission. The emitted gasses served as a trap to the outgoing longwave radiation that drives to change the earth's surface temperature and other atmospheric processes. The new findings on the study of Fahey et al. (2017) say that aside from changes in greenhouse gasses emissions, small airborne particles like aerosols produced from smallscale human activities are now a significant driver of climate change. In the Philippines, the total greenhouse gas emissions based on the USAID current report were 157.6 million metric tons of carbon dioxide equivalent to $0.33 \%$ global greenhouse gas emissions (GHG). 54\% of GHG in the country came from the energy sector, followed by agriculture $(33 \%)$, industrial processes $(8 \%)$, wastes and land-use change $(7 \%)$, and forestry sectors $(1 \%)$. This phenomenon has ecological, social, and economic impacts in the Philippines and the entire world that need immediate attention and actions by all stakeholders.

Climate change is one of the contemporary environmental problems facing many countries, particularly in the Asia region. It refers to change in the state of climate over time, whether caused by natural variability and human activities (Alexander et al., 2013). In recent decades, climate change caused impacts on the human and natural system (Field and et al., 2015). In some cases like India, the increase in water body temperature profoundly affects the reproductive cycle and productivity of marine organisms that cause a decline in production (Ninawe, Arun, Indulkar, Sudhakar T., \& Amin, 2018). Another impact of climate change experience in Asia is the sea level rise that affects both communities and biodiversity. Sea level rise is another impact of climate change experience in Asia. The projected increase of sea level in Samutsakorn, Thailand, is with an additional $27 \mathrm{~cm}$ in 2050 (Monprapussor, 2018). Coastal erosion and coastal habitat destruction are impacts of sea-level rise (Ninawe, Indulkar, \& Amin 2018). Another impact of climate change is the storm surge. North Coast of Vietnam experiences storm surge due to climate change that affects the biodiversity and habitat (Thai, Thuy, Dang, Kim, and Hole 2017).

Also, the protection and management of mangroves can play an essential role in the adaptation and mitigation of local communities to climate change impacts. Specifically, mangroves prevent erosion in the case of sea-level rise and sequester carbon in their sediments to mitigate the emission of carbon dioxide that causes global warming (Breithaupt, Smoak, \& T.J., 2012). In Asia, Myanmar is one of the countries that are most vulnerable to climate change. With this, mangrove rehabilitation and management served as adaptation and mitigation measures. Coastal community forest groups were established to apply sustainable mangrove management. A minimum of 20,000 acres of mangrove forest was restored (Ministry of Foreign Affairs of Denmark, 2017).

Thus, this phenomenon has an impact on biodiversity and on the community like the indigenous cultural community. This aims to determine the impacts of climate change on the 
biodiversity and indigenous people in the province of Palawan and their adaptation and mitigating measures to improve resiliency against climate change impacts.

\section{Impacts of Climate Change in the Philippines}

The Philippines is significantly experiencing impacts of climate change such as sea-level rise, storm surge, destruction of habitat, extinction of flora and fauna species, life cycle changes, changes in surface water availability, and changes in aquatic and terrestrial productivity. Based on the current report of PAG-ASA, the annual mean temperature in all areas in the country, the increases have been from $0.57^{\circ} \mathrm{C}$ and are expected to increase by $0.9^{\circ} \mathrm{C}$ to $1.1{ }^{\circ} \mathrm{C}$ in 2020 and $1.8^{\circ} \mathrm{C}$ to $2.2{ }^{\circ} \mathrm{C}$ in 2050. The World Meteorological Organization 2019 report shows that year 2019 is likely the second warmest in instrumental records. Also, the country experiences an average of 20 tropical cyclones formed per year and extreme rainfall of higher than $300 \mathrm{~mm}$ rainfall that damages people's lives and properties, and wildlife.

The Luzon areas in the country experienced a decline in rice, corn, and other agricultural products, a decline in water supply for agricultural and domestic use, typhoons, volcanic eruption, changes in biodiversity and habitat. Central Luzon is known as the "Rice Bowl of the Philippines" and ranked high to very high on risk based on the Risk to Typhoons and risk to Projected Rainfall Change maps of the Manila Observatory. Over 3,000 farmers in Central Luzon experience damages to crops due to extreme weather and a decline of water supply for irrigation. Also, in Isabela province, corn production was declined in the past years due to extreme weather conditions, an increase in annual temperature, and changes in rainfall patterns based on the study of Alcaide et al. (2019). Also, the Taal volcanic eruption affected at least 151,386 families and caused disturbances of wildlife and their habitat like Tawilis(Sardinella tawilis). These phenomena affect the realization of the long-term goals of our nation for the general welfare of the people.

In some areas in the Visayas, Eastern Samar and Sagay Negros Occidental were hit by a typhoon Yolanda last November 2013. In Eastern Samar, there were lives killed and destroyed properties. There are approximately 3,432 people who died, and 12,000 were injured in Eastern Visayas during the typhoon hit, in which Eastern Samar is one of the most affected areas (Ranada, 2013). Massive defoliation, broken branches, and trunks, and uprooted trees are some impacts of the typhoon to some areas of the mangrove forest of Eastern Samar. Based on the study of Primavera et al. (2016), the mangrove cover of Eastern Samar is 3,167 hectares, and the proportion of relatively undamaged trees was lower in Lawaan mixed forest and Gen. MacArthur with $15-16 \%$ and zero in the single plantation and the directly hit mangroves of Guiuan and Hernani.

In the case of Sagay, Negros Occidental, the lives of people were saved by the 4-hectare mangroves against the storm surge caused by the typhoon. This mangrove forest is a portion of the 32,000-hectare Sagay Marine Reserve. Mangrove forest served as a barrier against storms but was destroyed by the typhoon (FFE Magazine, 2013). It saved approximately 5,000 residents in Sagay Island (Philippine National Volunteer Service Coordinating Agency, 2015)(Piccio, 2014), but some essential properties like fish boats and houses were damaged (Tulali, 2014). The mangroves are still standing, but the branches were cut down and no leaves, especially in the middle part of the mangrove area (Gomez, 2013). Mangroves are a very crucial resource in Sagay, in which most residents are highly dependent on it. The residents enjoyed the benefits provided by mangroves, such as the increase of seafood, particularly crabs, shells, and fishes (Philippine National Volunteer Service Coordinating Agency, 2015).

\section{Climate Change Impacts on Biodiversity in Palawan}

Palawan has a land area of 1,489,655 hectares and the largest province in the Philippines. It has rich biodiversity and is considered the "Last Ecological Frontier" of the country. The presence of rich biodiversity in the province provides goods and services to the local community, such as fishes, crabs, shrimps, shells, forest products, and many others. Specifically, the province has diverse species of flora and fauna such as the country's endemic amphibians (8 species), birds (279 species), marine mammals (15 species), terrestrial mammals (58 species), endemic reptiles (24 species), and many others (see Table 1). Also, rich biodiversity contributes to increasing the resilience of both upland and coastal communities by providing food security, livelihood opportunities, and protection.

Table 1: Palawan Biodiversity (Source: PNNI, 2018)

\begin{tabular}{|c|c|}
\hline Palawan Biodiversity & Current Status \\
Mangrove Forest & $\begin{array}{c}42,000 \text { hectares with 31 species } \\
\text { present in the province }\end{array}$ \\
\hline Seagrasses & 13 species present \\
\hline Coral Reefs & 379 species present \\
\hline $\begin{array}{c}\text { Country's } \\
\text { EndemicAmphibians }\end{array}$ & 8 species present \\
\hline Marine Mammals & 15 species present \\
\hline Terrestrial Mammals & 58 species present \\
\hline Endemic Reptiles & 24 species present \\
\hline Birds & 279 species present \\
\hline
\end{tabular}

Table 2 shows the habitat of flora and fauna in the province. There are different habitat that can be found in the province that highly supports the biodiversity based on PNNI (2018) which includes: mangrove forest (approximately 42,000 has with 31 species), terrestrial forest $(690,000$ hectares $)$, seagrasses (13 species present), coral reefs (379 species present), lakes (15 major lakes), ponds (42), waterfalls (44), natural springs (72), streams (43), and creeks (165).

Table 2: Habitat of Flora and Fauna in Palawan (Source: PNNI, 2018)

\begin{tabular}{|c|c|}
\hline $\begin{array}{c}\text { Habitat of Flora and } \\
\text { Fauna in Palawan }\end{array}$ & Current Status \\
\hline Terrestrial Forest & $\begin{array}{c}\text { There are approximately 690,000 hectares } \\
\text { of terrestrial forest in the entire province }\end{array}$ \\
\hline Mangrove Forest & $\begin{array}{c}\text { The province has 42,000 hectares of } \\
\text { mangroves with 31 species }\end{array}$ \\
\hline Lakes & 15 major lakes located in the province \\
\hline Pond & 42 ponds \\
\hline Waterfalls & $\begin{array}{c}\text { 44 waterfalls can be found in different } \\
\text { municipalities and city in the province }\end{array}$ \\
\hline
\end{tabular}




\begin{tabular}{|c|c|}
\hline Natural Springs & 72 natural springs \\
\hline Streams & 43 streams \\
\hline Creeks & 165 identified creeks \\
\hline
\end{tabular}

The province experiences impact of climate change such as extreme weather, storms, floods, destruction of habitats, pests and diseases, disturbances of flora and fauna species, changes in water availability, and changes in aquatic and terrestrial productivity and others. The small islands in the province of Palawan are affected by the typhoon. Like in the case of Calauit Island, after the hit of Typhoon Yolanda last November 8, 2013, the island was profoundly devastated, which caused damage to the coastal community, mangrove area, and coastal biodiversity based on the study of the Malabrigo and others (2016). It has approximately 500-ha of mangrove forests in Ilultuk Bay. There are 60\% of the mangrove forests in Cluster 1 of Sitio Calauit, Bgy. Buluang was profoundly devastated by Typhoon Yolanda, and $5 \%$ felled, and the majority defoliated. The recorded total damage is Excoecariaagallocha with a diameter breast height of $12 \mathrm{~cm}$. Rhizophora apiculata has the highest percentage of defoliated trees with $53.13 \%$, and most of the trees have a diameter class of $3 \mathrm{~cm}$.

Mangrove forests are highly significant forests that grow in the coastal area, which stabilize coastlines, protect communities from storms, provide critical habitats for many animals, and store vast amounts of carbon. For the past decades, there has been a huge decrease in areas occupied by mangrove trees in the Philippines. At present, the mangrove forest cover in the country is estimated at 310,593 hectares (DENR, 2015), having dwindled from 450,000 ha in 1918 (Naz, 2013). This significant loss of mangrove forests can be attributed to anthropogenic activities, especially converting mangrove forests to fishponds or aquaculture and clear-cutting for timber production (Carter et al., 2015). Based on Morales and others (2014), aside from aquaculture, tourism activities can destroy the mangrove forests. From 1973 to 2002, a total of $62,834.34$ hectares of mangrove forest areas across the country were issued with Fishpond Lease Agreements (FLAs) by the Bureau of Fisheries and Aquatic Resources (BFAR), consequently converting these forests into fishponds (Naz, 2013). Fish production will rapidly decline due to uncontrolled and continuous mangrove deforestation and no proper management and restoration programs (Carter et al., 2015).

Out of the total land area of 1.485 million hectares of Palawan, $4.4 \%$ or 63,532 hectares is saturated with mangroves, and it is considered the highest in the country. This presents a significant increase in the province's mangrove cover compared to $3.34 \%$ in $1992,3.35 \%$ in 1998 , and $4.0 \%$ in 2005 , with an approximate increase rate of 700 hectares/year (PCSD, 2015). In line with the rising awareness of the importance of mangroves, governmentfunded and large-scale international development assistance programs have focused on mangrove replanting or rehabilitation in Palawan and other parts of the country. However, with the current rate of development in the province and the expansion of its tourism industry, pressures caused by the people's demand will continue to threaten Palawan's mangrove forests (Primavera \& Esteban 2008).

In addition, Mount Mantalingahan is one of the protected areas in Palawan and the habitat of numerous flora and fauna, and endemic species. The extreme weather condition and increase in average temperature in the protected area cause disturbances to flora and fauna's life cycle and productivity (Fuentes et al., 2015). In the case of Bunog, Rizal, Palawan, particularly in the cultural area of Palaw'ans experiences a rapid increase of pests and diseases to endemic plants in the area due to the changes in average temperature and amount of rainfall (Roa et al., 2015). This highly affects the growth, reproduction, and productivity of plants and animals interacting (see Table 3 ).

Table 3: Biodiversity Impacts of Climate Change and Implemented Mitigating and Adaptation Strategies

\begin{tabular}{|c|c|c|}
\hline $\begin{array}{l}\text { Biodiversity } \\
\text { Impacts }\end{array}$ & Affected Area & Mitigation/Adaptation \\
\hline $\begin{array}{c}\text { Defoliated } \\
\text { mangrove trees }\end{array}$ & $\begin{array}{c}\text { Majority of the } \\
\text { mangrove area in } \\
\text { Cluster } 1 \text { of Sitio } \\
\text { Calauit, Bgy. } \\
\text { Buluang, Busuanga, } \\
\text { Palawan }\end{array}$ & $\begin{array}{l}\text { Avoid disturbances within } \\
\text { areas with defoliated } \\
\text { mangrove trees to support } \\
\text { natural regeneration }\end{array}$ \\
\hline $\begin{array}{c}\text { Felled Mangrove } \\
\text { Trees }\end{array}$ & $\begin{array}{c}\text { Five percemt were } \\
\text { felled in Cluster } 1 \text { of } \\
\text { Sitio Calauit, Bgy. } \\
\text { Buluang, Busuanga, } \\
\text { Palawan }\end{array}$ & $\begin{array}{c}\text { Use rope and stick/wood to } \\
\text { support the felled } \\
\text { mangrove trees } \\
\text { Avoid disturbances within } \\
\text { areas with felled mangrove } \\
\text { trees to support natural } \\
\text { regeneration }\end{array}$ \\
\hline $\begin{array}{l}\text { Pest and Diseases } \\
\text { to Endemic Plants }\end{array}$ & $\begin{array}{c}\text { Palaw'ans tribe in } \\
\text { Bunog, Rizal, } \\
\text { Palawan }\end{array}$ & $\begin{array}{c}\text { Pagpapausokor burning of } \\
\text { the roots }\end{array}$ \\
\hline $\begin{array}{l}\text { Disturbances to } \\
\text { life cycle and } \\
\text { productivity of } \\
\text { flora and fauna }\end{array}$ & $\begin{array}{c}\text { Mount } \\
\text { Mantalingahan }\end{array}$ & $\begin{array}{c}\text { Information Education } \\
\text { Campaign to increase } \\
\text { awareness and for } \\
\text { protection } \\
\text { Prohibit the harvesting and } \\
\text { disturbances within areas }\end{array}$ \\
\hline $\begin{array}{l}\text { Growth and } \\
\text { productivity of } \\
\text { crops }\end{array}$ & $\begin{array}{l}\text { Palaw'ans tribe in } \\
\text { Bunog, Rizal, } \\
\text { Palawan }\end{array}$ & $\begin{array}{l}\text { Prohibit the harvesting and } \\
\text { disturbances within areas }\end{array}$ \\
\hline
\end{tabular}

The future risks and vulnerability of mangrove forests in Palawan are due to reasons like the absence of highly adaptive mangrove species against strong waves and winds in front areas. For instance, mangrove species like Sonneratia alba are highly adaptive to strong waves. The case of mangrove adaptation to storm surge in Eastern Samar is evident in which many damaged mangrove trees, especially the Sonneratia alba, already have growing sprouts 4.5 months after the hit of Typhoon Yolanda (Primavera et al., 2016). In Balangkayan, Sonneratiahas the highest survival rate and started to grow sprouts (Alura et al., 2015). Also, human anthropogenic activities like mass tourism, aquaculture, and illegal cutting of mangroves in some areas can increase the risks and vulnerability of mangroves in Palawan for future disturbances.

The local community, including the government in Calauit, more strengthens their perception of the importance of mangroves. They learned that mangroves can save the 
coastal community in the case of disasters like a storm surge. In this case, planting and protecting mangroves as a long-term adaptation measure is very helpful in increasing the coastal resiliency not only in livelihood support but also in shielding storm surge, sea-level rise, and coastal erosion as the impact of climate change. Vulnerability, exposure, and climate-related hazards are determinants of climate change impacts (Field and others, 2015). Researches are an important part of adaptation against climate change. In developing countries, the number of publications has increased but still represents a small fraction of the total (Field et al., 2015). Also, continuous provision of information through research is a useful tool in long-term adaptation for us to fully understand mangroves in Palawan in terms of adaptation, recovery, etc., as a basis for suitable policies, strategies, and actions. Relevant policies, institutional support, technological and socio-economic support such as researches on climate change impacts, adaptation, comprehensive assessment of mangrove forest and biodiversity, monitoring and evaluation policy of mangrove forest and biodiversity, provision of technologies, and excellent strategies in managing the biodiversity and crops, strong support of the institution in providing the market of the products produced by the local community and provision of training and capital on the livelihood of the people that are dependent on forest and many others. With this, the resiliency of biodiversity against climate change impacts will be improved and lessen future vulnerabilities.

\section{Climate Change Impacts on Indigenous People in Palawan}

There are numerous Indigenous Cultural communities in Palawan, such as Palaw'an, Batak, Tagbanua, Molbog, Tau'tBato, etc. They have their traditional knowledge and practices in farming, fishing, and other livelihood activities. These tribes are commonly practicing "Kaingin" as their primary farming practices but with different belief systems and traditional knowledge and practices. The common crops planted are rice, cassava, sweet potato, corn, and banana. These crops are highly sensitive to changes in temperature and rainfall patterns. Thus, their farming practices are highly vulnerable to climate change.

The livelihood farming activity of Palaw'ans in Bunog, Rizal, Palawan is highly affected by climate change. Roa et al. (2015) study show that climate change has notable effects on the crop harvest of tribe members, especially rice. The tribe members observed several changes in the past years, like the $90 \%$ decrease in the harvest and rapid increase of pest occurrence in their farmland, kaingin. The food security of the tribe for the whole year is at risk due to the decline of crop harvest. However, the tribe has traditional knowledge on the adaption of climate change impacts like "Pagpapausok" or the burning of the roots as their adaptation measures to lessen pests and diseases. Also, to have an alternative source of income, they engaged in handicrafts like making baskets that they can sell to the local market.

In addition, the case of the Tagbanua tribe in Calauit Island, which was highly affected by Typhoon Yolanda last November 8, 2013. The entire island was highly devastated, which caused damage to the Tagbanua tribe and other local people as well as the mangrove area based on the study of Malabrigo et al. (2016). There are about 6,544 affected families with damaged properties. Aside from the damage of their properties are the displacement of animals and the destruction of habitat.

Calauit Island is one of the small islands located in Northern Palawan. The part of Ilultuk Bay has a large mangrove forest with approximately 500 hectares. The Tagbanua tribe depends on ecosystem services provided by the mangrove forest for their traditional practices and daily subsistence. They can harvest fishes, crustaceans, and shells for both household consumption and commercial use. Last November 8, 2013, Calauit island was highly devastated during the landfall of Typhoon Haiyan, locally known as Typhoon Yolanda that caused damage to the mangrove area. Also, mangroves served as a buffer to the tribe against disturbances that lessen the impact of the typhoon. Tagbanuas are highly dependent on mangroves in terms of their traditional livelihood practices like gleaning or "Panginginas" and fishing. This disaster caused a lack of source of income and food insecurity. Also, the traditional practices dependent on mangrove forest-like "panginginas" are affected (see Table 4).

In addition, in San Vicente, Palawan, the fishing livelihood of the Tagbanuas is affected by the decline of fish catch due to the perceived climatic factors based on the study of Buncag (2019) directly affect their daily subsistence. Shifting from fishing to tourism-related activities is their adaptation measures to provide everyday needs.

Table 4: Impacts of Climate Change on Indigenous People and Implemented Mitigating and Adaptation Strategies

\begin{tabular}{|c|c|c|}
\hline $\begin{array}{c}\text { Impacts on } \\
\text { Indigenous People }\end{array}$ & Affected Area & Mitigation/Adaptation \\
\hline $\begin{array}{c}\text { Decline of rice crop } \\
\text { harvest from Kaingin } \\
\text { farming for the } \\
\text { subsistence of each } \\
\text { family }\end{array}$ & $\begin{array}{c}\text { Palaw'an tribe } \\
\text { in Bunog, } \\
\text { Rizal, Palawan }\end{array}$ & $\begin{array}{c}\text { Use of Calendar Method for } \\
\text { Planting and Harvesting }\end{array}$ \\
\hline $\begin{array}{c}\text { Decline of water } \\
\text { availability } \\
\text { accessible to the area }\end{array}$ & $\begin{array}{c}\text { Palaw'an tribe } \\
\text { in Bunog, } \\
\text { Rizal, Palawan }\end{array}$ & $\begin{array}{c}\text { Improvised pipe made of } \\
\text { bamboo stem (spring) }\end{array}$ \\
\hline $\begin{array}{c}\text { Decline of gathered } \\
\text { forest products of } \\
\text { about 80\%-90\% } \\
\text { based on estimation }\end{array}$ & $\begin{array}{c}\text { Palaw'an tribe } \\
\text { in Bunog, } \\
\text { Rizal, Palawan }\end{array}$ & $\begin{array}{c}\text { No identified adaptation } \\
\text { measure implemented by the } \\
\text { tribe }\end{array}$ \\
\hline $\begin{array}{c}\text { Damaged properties } \\
\text { in Calauit } \\
\text { Island }\end{array}$ & $\begin{array}{c}\text { Tagbanua tribe } \\
\text { increase coastal community } \\
\text { resiliency }\end{array}$ \\
\hline $\begin{array}{c}\text { The decline of } \\
\text { gathered products } \\
\text { from gleaning and } \\
\text { fishing }\end{array}$ & $\begin{array}{c}\text { Tagbanua tribe } \\
\text { in Calauit } \\
\text { Island }\end{array}$ & $\begin{array}{c}\text { Planting and protection of } \\
\text { mangroves and coral reef }\end{array}$ \\
\hline $\begin{array}{c}\text { The decline of } \\
\text { gathered products } \\
\text { from fishing }\end{array}$ & $\begin{array}{c}\text { Tagbanua tribe } \\
\text { in San Vicente, } \\
\text { Palawan }\end{array}$ & Protection of coastal area \\
\hline
\end{tabular}

Some communities in Palawan with high risk in the future occurrence of flood and sea-level rise as climate change impacts. The municipality of Taytay, Palawan, has a high risk of the occurrence of flood and sea-level rise. A total of 10, 759.9 hectares were identified as flood-prone areas, in which 481.9 hectares are in Eastern Taytay and 10,278.9 
hectares in Western Taytay (PCSD, 2017). In the case of Balabac Municipality, Palawan, around $7 \%$ of the total land area has very high exposure to flooding which includes Poblacion IV (67\%), Poblacion II (47\%), Melville (32\%), Cataguspan (29\%), Poblacion I (23\%) and Poblacion V $(21 \%)$. As predicted, the municipality of Taytay has $1,789.1$ hectares prone areas to sea-level rise and the Balabac has a 0.5 meter sea level rise (PCSD, 2017).

Also, the local community's farming and fishing livelihood activities are at risk from future climate change impacts. In the case of Bunog, Rizal, the tribe members experienced a $90 \%$ decrease in the harvest and a rapid increase of pest occurrence in their farmland (Roa et al., 2015).In San Vicente, Palawan, fishing communities experienced a decline of fish catch for the past years due to perceived climatic factors (Buncag, 2019). So, the food security of the tribe and other local communities for the future is at risk due to the low resiliency against climate change impacts.

\section{Climate Change Adaptation of Coastal Communities and Indigenous People in Palawan}

For instance, some ongoing Community-Based Forest Management in Palawan is managed by Indigenous Cultural Community (Tagbanua and Palaw'an tribes). One of these is in the Mangrove Forest of Tagpait, Aborlan. Based on the study of Regoniel\&Pacañot (2012), since this is not part of the mangrove reserve of Palawan, cutting of mangrove is allowed by their organization, Tagpait Coastal Development Association (TACDA), for every member but with control measure. The use of mangroves is only for housing lumber needs as well as aquaculture (shrimps, crabs, and fishes). Also, the cutting of mangroves by people from other places or adjacent barangays is a significant problem in the area. Currently, the mangrove uses by the local community through tourism activities as the primary source of income (Dela Peña and others 2013). The community experienced a flood that affects their livelihood, but with the presence of mangrove forests, the impact is not severe. As a response of the community, they continuously protect the community their afforested mangrove, they replaced cut trees and planted the vacant areas. They perceived as a community that, with the presence of mangroves, they could be resilient against disasters and climate change impacts (Buncag, 2020).

Another one is the community-based mangrove forest management in Bacungan, Puerto Princesa City, managed by Cuyonon and Tagbanua tribes. The ABS-CBN Foundation and the City Government of Puerto Princesa City implemented mangrove management in approximately 378 hectares. Until now, the area was engaged in tourism activity through paddle boating, floating restaurant, etc. and primarily being managed by the Bacungan Mangrove Ecotourism Service Cooperative (Buncag, 2020). The primary livelihood of the community is fishing and farming. In the case of flood occurrence, storms and strong wind, they are not highly affected due to the presence of mangrove forests that serve as a buffer. With this, they are continuously managing the mangrove forest to maintain and improve their resiliency against disasters and impacts of climate change. Also, they are currently planting mangroves in vacant areas using propagules of different species suitable in a specific area.

As a future adaptation strategy, the local communities of San Vicente, Palawan, are planning to shift from fishing to tourism-related livelihood to maintain or increase their income for their subsistence (Buncag, 2019). Adaptations can increase the capacity of society to cope with climate change impacts (Field et al., 2015). Also, the provision of excellent policies and strategic actions in terms of alternative livelihood, economic support, sufficient training, and technological support from various institutions in the management of crops, fisheries, upland forest, mangroves, etc. will help to increase the resiliency of the tribes or local communities against future risks to climate changes impacts.

\section{Conclusion}

The province experiences impact of climate change such as extreme weather, storms, floods, destruction of habitats like mangroves, pests and diseases, disturbances of flora and fauna species, changes in water availability, and changes in aquatic and terrestrial productivity. There are numerous Indigenous Cultural communities in the province of Palawan, such as Palaw'an, Batak, Tagbanua, Molbog, Tau'tBato. They have their traditional knowledge and practices in farming, fishing, and other livelihood activities. These tribes are commonly practicing "Kaingin" as their primary farming practices but with different belief systems and traditional knowledge and practices. The common crops planted are rice, cassava, sweet potato, corn, and banana. These crops are highly sensitive to changes in temperature and rainfall patterns. Thus, their farming practices are highly vulnerable to climate change.

\section{Recommendations}

All stakeholders' direct efforts to fulfill AmBisyonNatin 2040 are highly recommended by working on housing and development programs, resilient manufacturing facilities, education services, tourism services, sustainable agriculture, health services, transportation, and communication, and financial services. In addition, some mitigation and adaptation strategies in climate change that can be implemented are highly adaptive and resilient dams for water supply, irrigation and hydropower, river defenses through increase dam's height and reservoir capacity, consumption and behavioral change and change in infrastructure designs, wildlife protection, natural habitat protection, and rehabilitation and others. Palawan has rich biodiversity in both terrestrial forests and mangrove forests. It needs a balanced treatment to protect terrestrial forests and mangrove forests to increase future resiliency against climate change impacts. Also, increasing the resiliency of habitat that can lessen the impacts of climate change, which can provide coastal community resiliency.

Palawan is a province surrounded by seas and vulnerable to climate change impacts like sea-level rise, strong waves, flood, storm surge, and many others. The mangrove forest is a crucial ecosystem that provides support from storm surge, flood, sea-level rise, coastal erosion, and strong wind, 
carbon sequestration, a habitat of different marine and migratory organisms, supporting human livelihood, and increasing coastal vulnerability community resiliency. It mitigates climate change impacts like sea-level rise and storm surge, but it can be negatively affected by these impacts. The presence of huge healthy mangroves in the coastal area can increase coastal resiliency against climate change impacts that will improve coastal community resiliency.

Proper coastal area protection and management should support the mangrove natural recovery to have a resilient ecosystem beneficial to the local community. However, this requires a comprehensive site assessment of the mangrove area (Schmitt \& Duke 2016). Comprehensive site assessment of the mangrove ecosystem has some significant indicators that should be considered, including species of flora and fauna, sediment deposit, regenerants, tidal characteristics, policies and institutions, socio-demographic characteristics, and other relevant variables. Aside from full site assessment is applying the engineering approach that is needed for recovery and restoration of mangroves to attain resiliency of the communities.

The disaster mitigation plan for post-Yolanda includes rehabilitation and recovery by replanting and recovering damaged mangroves, constructing and rehabilitating more resilient houses, and at a safer place against disasters like typhoons and awareness campaigns. Also, the study from Malabrigo et al. (2016), recommended some mitigating measures that guided the disaster mitigation plan of Calauit Island, which includes: monitoring of growth, regeneration, and recovery of impacted mangroves; cleaning of debris and liberation cutting of dead standing trees, enrichment planting in areas where there is massive mortality; continued protection of mangrove forest; continued awareness campaign on the importance of mangroves; and development of an ecotourism module for Calauit. This strategy can be applied to other areas in order to improve resiliency.

Climate change impacts have no boundary, and every individual is affected. In this case, collective actions by all stakeholders such as national government agencies, nongovernment organizations, communities, local government units, academe, and others are highly needed to mitigate the drivers and impacts of climate change. Let us help each other to save our planet against climate change by providing simple actions to attain AmBisyonNatin 2040, which is beneficial to the general welfare of both present and future generations.

\section{References}

[1] Alexander, L., Allen, S., Binfodff, N., Breon, F.-M., Church, J., Cubasch, U., ... Xie, S.-P. (2013). Climate Change 2013 : The Physical Science Basis. Summary for Policymakers. 4(1), 1-31. https://doi.org/10.1002/adfm.200800528

[2] Alcaide, K., Buncag, M.J, Mendoza, R.E., and Santos, B. (2019). Developing a Rainfall-based Index for Corn Crop Insurance in Isabela, Philippines. International
Journal of Science and Management Studies. 2 (6), 77-84.

[3] AmBisyon Natin 2040 (2015). A Long-term Vision for the Philippines.

[4] Breithaupt, J. L., Smoak, J. M., \& T.J., S. (2012). Mangroves provide both climate mitigation and adaptation services.

https://doi.org/10.1029/2012GB004375.

[5] Buncag, M. J. (2020). Sustainability Analysis of Mangrove Forest Management Systems in Tagpait, Borlan and Bacungan, Puerto Princesa City, Palawan, Philippines.

[6] Buncag, M.J. (2019). From Fishing to Tourism: A Livelihood Transition in San Vicente, Palawan. Asian Journal of Resilence. 1(1), 17-26.

[7] Blanco, G., Gerlagh, R., Suh, S., Barrett, J., de Coninck, H. C., Diaz Morejon, C. F., ... Zhou, P. (2014). Drivers, Trends and Mitigation. Climate Change 2014: Mitigation of Climate Change. Contribution of Working Group III to the Fifth Assessment Report of the Intergovernmental Panel on Climate Change. 351-412. https://doi.org/10.2800/93693

[8] Carter, H. N., Schmidt, S. W., \&Rons, A. C. (2015). An International Assessment of Mangrove Management: Incorporation in Integrated Coastal Zone Management. Diversity Journal, 7(1), 74-104. DOI:10.3390/d7020074.

[9] C.B. Field, V.R. Barros, K.J. Mach, M.D. Mastrandrea, M. van Aalst, W.N. Adger, D.J. Arent, J. Barnett, R. Betts, T.E. Bilir, J. Birkmann, J. Carmin, D.D. Chadee, A.J. Challinor, M. Chatterjee, W. Cramer, D.J. Davidson, Y.O. Estrada, J.-P. Gattuso, Y. Hijioka, O. Hoegh-Guldberg, H.Q. Huang, G.E. Insarov, R.N. Jones, R.S. Kovats, P. Romero-Lankao, J.N. Larsen, I.J. Losada, J.A. Marengo, R.F. McLean, L.O. Mearns, R. Mechler, J.F. Morton, I. Niang, T. Oki, J.M. Olwoch, M. Opondo, E.S. Poloczanska, H.O. Pörtner, M.H. Redsteer, A. Reisinger, A. Revi, D.N. Schmidt, M.R. Shaw, W. Solecki, D.A. Stone, J.M.R. Stone, K.M. Strzepek, A.G. Suarez, P. Tschakert, R. Valentini, S. Vicuña, A. Villamizar, K.E. Vincent, R. Warren, L.L. White, T.J. Wilbanks, P.P. Wong, and G.W. Yohe, (2014): Technical summary. In: ClimateChange 2014: Impacts, Adaptation, and Vulnerability. Part A: Global and Sectoral Aspects. Contribution of WorkingGroup II to the Fifth Assessment Report of the Intergovernmental Panel on Climate Change [Field, C.B., V.R. Barros, D.J. Dokken, K.J. Mach, M.D. Mastrandrea, T.E. Bilir, M. Chatterjee, K.L. Ebi, Y.O. Estrada, R.C. Genova, B. Girma, E.S. Kissel, A.N. Levy, S. MacCracken, P.R. Mastrandrea, and L.L. White (eds.)]. Cambridge University Press, Cambridge, United Kingdom and New York, NY, USA, pp. 35-94.

[10] Dela Peña, H. P., Flores, C. G., Buncag, M.J. J., Lubrico, L. Y. \&Pacañot, E. B. (2013). Ecotourism in Community-Based Mangrove Afforestation in Tagpait, Aborlan, Palawan. BIMP-EAGA Journal for Sustainable Tourism Development. 2(2), 47-50.

[11] Diaz-sierra, R., Enríquez-de-salamanca, Á., Díazsierra, R., Martín-aranda, R. M., \& Santos, M. J. (2017). Environmental impacts of climate change 
adaptation. Environmental Impact Assessment Review, 64(February 2018). 87-96. https://doi.org/10.1016/j.eiar.2017.03.005

[12] Environmental Protection Agency (2019). Global Greenhouse Gas Emissions Data. Retrieved at https://www.epa.gov/ghgemissions/globalgreenhouse-gas-emissions-data

[13] FFE Magazine. (2013). Mangroves save islands in Negros. Retrieved from http://ffemagazine.com/mangroves-save-islands-innegros/

[14] Fuentes, R., Pontillas, J., and Pido, M. (2015). The Role of UNESCO's Man and Biosphere Reserves in Climate Change Adaptation: Experience from Palawan Biosphere Reserve in the Philippines. The Scientific Journal of Palawan Council for Sustainable Development. 1 (1), 49-60.

[15] Lagare, J. (2020). Only $25 \%$ of LGUs have Sanitary Landfill. Manila Times Retrieved at https://www.manilatimes.net/2020/02/12/news/regions /only-25-of-lgus-have-landfills/684028/

[16] Malabrigo, P. L., Umali, A. G. A., \& Replan, E. L. (2016). Damage assessment and recovery monitoring of the mangrove forests in Calauit island affected by Typhoon Yolanda (Haiyan). Journal of Environmental Science and Management, 2016(Special Issue 2). 3946.

[17] Manalac, S. (2014). Effects of Climate Change to Rice Production: Central Luzon, Philippines.

[18] Ministry of Foreign Affairs of Denmark. (2017). Climate Change Adaptation: Management Mangrove Forests, Myanmar.

[19] Monprapussorn, S. (2018). Impact of climate and land use change on ecosystem services: A case study of Samutsakorn province, Thailand. Ecological Informatics, 47(February 2017), 45-49. https://doi.org/10.1016/j.ecoinf.2017.08.007

[20] Morales, M. I., Masagca, J T.., Araojo, A. E., \& Vargas, S. R. (2014). Coastal and Mangrove Ecotourism in Catanduanes island (Philippines): A Menace or a Bonus? International Conference on Latest Trends in Food, Biological and Ecological Sciences, Thailand. pp. 42-46 Retrieved at https://studyres.com/doc/7970560/coastal-andmangrove-eco-tourism-in-catanduanes-island

[21] Naz, A. C. (2013). The State of the Philippine Environment: An Update on Chapter 4 of the 1994 Philippine Human Development Report. PHDR Issue 2012/2013, 10. Human Development Network, 1-40.

[22] Ninawe, Arun, Indulkar, Sudhakar T. and Amin, A. (2018). Impact of climate change on Australian forest operations. Biotechnology for Sustainable Agriculture. 80(5), 299-308. https://doi.org/10.1080/00049158.2017.1395762

[23] PAG-ASA (2011). Climate Change in the Philippines. Retrieved at https://dilg.gov.ph/PDF_File/reports_resources/DILGResources-2012130-2ef223f591.pdf

[24] Palawan Council for Sustainable Development (2015). State of the Environment, Province of Palawan (Man and Biosphere Reserve), Philippines, 2015 Updates. Palawan Council for Sustainable Development, Puerto Princesa City, Philippines. 1-73.
[25] Palawan Council for Sustainable Development (2017). Assessment of Palawan Coastal and Marine Areas Vulnerability to Climate Change: A Compilation Cases. Planning and Techical Services Department.

[26] Palawan NGO Network, Inc. (2018). Palawan Biodiversity Facts and Figures. Retrieved at https://pnni.wordpress.com/palawan-biodiversityfacts-and-figures/

[27] Perera, O. \&Uzsoli, D. (2013). Infratructure at Odds with Biodiversity? Retrieved at https://www.cbd.int/financial/2017docs/wwfinfrastructuremain2017.pdf

[28] Philippine National Volunteer Service Coordinating Agency (2015). Mangrove Saved us from Typhoon Haiyan. Retrieved from http://www.pnvsca.gov.ph/news/page.php?article=ne ws/2015/2015-02-03

[29] Piccio, B. (2014). Ancient Floating Forest saves 700 people from the Most Violent Storm. Retrieved from http://www.choosephilippines.com/go/islands-andbeaches/1868/floating-forest-saves-people

[30] Primavera, J. H., dela Cruz, M., Montilijao, C., Consunji, H., dela Paz, M., Rollon, R. N., ... Blanco, A. (2016). Preliminary assessment of post-Haiyan mangrove damage and short-term recovery in Eastern Samar, central Philippines. Marine Pollution Bulletin. 109(2), 744-750. https://doi.org/10.1016/j.marpolbul.2016.05.050

[31] Primavera, J. H., \& Esteban, J. M. A. (2008). A Review of Mangrove Rehabilitation in the Philippines: Successes, Failures, and Future Prospects. Wetlands Ecology and Management, 16(5), 345-358.

[32] Regoniel, P. A., \&Pacañot, E. B. (2012). Family-based mangrove afforestation in Tagpait, Aborlan, Palawan: Sustaining the Drive Toward Sustainable Development. Palawan State University Journal. 2013, 5(1), 8-13.

[33] Roa, S., Domingo, K., Fedillaga, K., Hechanova, I., Natividad, J. and Docto, R. (2015). Climate Change Vulnerability of the Palaw'ans in Bunog, Rizal, Palawan, Philippines. BIMP-EAGA Journal for Sustianble Tourism Development. 4 (1). ISSN 2232 10603. 146-157

[34] Ranada, P. (2013). Yolanda/Haiyan Damaged at 9.46 Billion. Rappler. Retrieved from https://www.rappler.com/moveph/issues/disasters/typhoon-yolanda/43858-20131116yolanda-death-toll-ndrrmc-am-report

[35] Schmitt, K., \& Duke, N. C. (2016). Tropical Forestry Handbook. 1-29. https://doi.org/10.1007/978-3-64241554-8

[36] Thai, T. H., Thuy, N. B., Dang, V. H., Kim, S., \& Hole, L. R. (2017). Impact of the interaction of surge, wave and tide on a storm surge on the north coast of Vietnam. Procedia IUTAM, 25, 82-91. https://doi.org/10.1016/j.piutam.2017.09.013

[37] Tulali, C. (2014). Providing Shelters to Survivors of Super Typhoon Haiyan in Molocaboc Island, Sagay City, Negros Occidental. Retrieved from https://www.scribd.com/document/244055412/Providi ng-Shelters-to-Survivors-of-Super-Typhoon-Haiyanin-Molocaboc-Island-Sagay-City-Negros-Occidental 
[38] USAID (2016). Philippines Greenhouse Gas Emissions Factsheet. Climate Links Resource Library. Retrieved

https://www.climatelinks.org/resources/greenhousegas-emissions-factsheet-philippines

[39] World Meteorological Organization (2019). WMO Statement on the State of Global Climate in 2019. WHO-No. 1248. 